\title{
ANALISIS VEGETASI GULMA PADA PERTANAMAN JAGUNG DAN HUBUNGANNYA DENGAN PENGENDALIAN GULMA DI LAMBUNG BUKIT, PADANG, SUMATERA BARAT
}

\author{
Ade Ayu Oksari \\ Program Studi Biologi FMIPA Universitas Nusa Bangsa Bogor \\ Jl. KH. Soleh Iskandar KM 4 Cimanggu Tanah Sareal, Bogor 16166 \\ *email : adeayuoksari@gmail.com
}

\section{ABSTRACT
The Vegetation Analysis of Weeds in Corn (Zea mays L.) Plantation and Its Conjunction with Weed Control in Lambung Bukit, Padang, West Sumatra

\begin{abstract}
Research about the vegetation analysis of weeds in corn (Zea mays L.) plantation and its conjunction with weed control in Kelurahan Lambung Bukit, Padang, West Sumatra had been conducted from March to Juny 2011 by using systematic squares method of 10 total plots with size $1 \times 1 \mathrm{~m}^{2}$. It was found consist of 10 families, 15 genera,16 species and 1892 individuals weeds. Spermacoce alata (Rubiaceae) showed the highest value of Summed Dominance Ratio $(23,17 \%)$ and the lowest rate of SDR Hedyotis sp., Cyperus cephalotes and Amaranthus sp. (0,65\%). The diversity index of the weeds was $H^{\prime}=1,2005$ (moderate). Integrated weed management is a concept that prioritizes natural control by creating environmental conditions that not favorable for the development of weeds and improve the competitiveness of crops against weeds.
\end{abstract}

Keywords: Weeds, corn, composition, structure, control

\begin{abstract}
ABSTRAK
Penelitian mengenai analisis vegetasi gulma pada pertanaman jagung dan hubungannya dengan pengendalian gulma di Kelurahan Lambung Bukit, Padang, Sumatera Barat telah dilaksanakan dari bulan Maret sampai Juni 2011. Penelitian dilakukan dengan menggunakan Metode Kuadrat sebanyak 10 plot dengan ukuran 1x1 $\mathrm{m}^{2}$. Pada penelitian ini didapatkan 10 famili, 15 genus, 16 jenis, dan 1892 individu gulma. Gulma yang memiliki nilai SDR tertinggi yaitu gulma jenis Spermacoce alata famili (Rubiaceae) dengan nilai Summed Dominance Ratio (SDR) 23,17\% dan nilai SDR terendah Hedyotis sp., Cyperus cephalotes dan Amaranthus sp. (0,65\%). Nilai indeks dari keanekaragaman jenis gulma berada pada nilai $\mathrm{H}^{\prime}=1,2005$ (sedang). Pengelolaan gulma terpadu merupakan konsep yang mengutamakan pengendalian secara alami dengan menciptakan keadaan lingkungan yang tidak menguntungkan bagi perkembangan gulma dan meningkatkan daya saing tanaman terhadap gulma
\end{abstract}

Kata Kunci: Gulma, Jagung, Komposisi, Struktur, Pengendalian

\section{PENDAHULUAN}

Jagung (Zea mays L.) merupakan palawija sumber karbohidrat yang memegang peranan penting kedua setelah beras. Jagung juga mengandung unsur gizi lain yang diperlukan manusia yaitu energi dalam bentuk kalori dan protein. Kandungan gizi jagung tidak kalah dengan beras atau terigu, bahkan jagung memiliki keunggulan karena merupakan pangan fungsional yaitu makanan dan bahan pangan yang dapat memberkan manfaat tambahan. Di samping fungsi gizi, juga sebagai sumber karbohidrat berupa kandungan serat pangan, unsur $\mathrm{Fe}$ dan $\beta$ karoten (pro-vitamin A) yang tinggi (Suarni, 2001). Jagung merupakan salah satu tanam- an serealia yang tumbuh hampir diseluruh dunia dan tergolong spesies dengan variabilitas genetik yang besar dan dapat menghasilkan genotipe baru yang dapat beradaptasi terhadap berbagai karakteristik lingkungan (Purwono dan Hartono, 2008).

Salah satu faktor pembatas dalam meningkatkan produksi jagung yang dibudidayakan adalah gulma. Gulma adalah suatu tumbuhan lain yang tumbuh pada lahan tanaman budidaya, tumbuhan yang tumbuh disekitar tanaman pokok (tanaman yang sengaja ditanam) atau semua tumbuhan yang tumbuh pada tempat (area) yang tidak diinginkan oleh si penanam sehingga kehadirannya dapat merugikan tanaman lain yang ada di dekat atau disekitar tanaman pokok 
tersebut (Moenandir, 1990). Selanjutnya, Rukmana dan Saputra (1999) mengatakan bahwa gulma adalah tumbuhan yang tidak dikehendaki yang mengganggu usaha manusia dalam mencapai kesejahteraan dan memiliki kemampuan kompetitif dan agresif serta tumbuhan yang kukuh (gigih) dan tahan pengendalian.

Pemeliharaan tanaman jagung secara intensif tidak terlepas dari aspek pengendalian gulma, karena kehadiran gulma pada pertanaman jagung sering dianggap sebagai salah satu penyebab turunnya hasil dan mutu biji jagung. Penurunan hasil tersebut sangat tergantung pada jenis gulma, tingkat kepadatan, waktu kompetisi, serta senyawa alelopati yang dikeluarkankan oleh gulma. Akibat yang terjadi dari penurunan tersebut adalah kehilangan hasil yang dapat melebihi kehilangan hasil yang disebabkan oleh hama dan penyakit pada tanaman (Kastanja,2012). Beberapa penelitian menunjukkan korelasi negatif antara bobot kering gulma dan hasil jagung, dengan penurunan hasil hingga 95\% (Violic, 2000). Di tingkat petani, kehilangan hasil jagung karena persaingan dengan gulma mencapai 10-15\% (Moenandir,1990). Hal ini berarti kehadiran gulma pada lahan pertanaman jagung tidak jarang menurunkan hasil dan mutu biji.

Keberhasilan pengendalian gulma merupakan salah satu faktor penentu tercapainya tingkat hasil jagung yang tinggi. Gulma dapat dikendalikan melalui berbagai aturan dan karantina; secara biologi dengan menggunakan organisme hidup; secara fisik dengan membakar dan menggenangi, melalui budi daya dengan pergiliran tanaman, peningkatan daya saing dan penggunaan mulsa; secara mekanis dengan mencabut, membabat, menginjak, menyiang dengan tangan, dan mengolah tanah dengan alat mekanis bermesin dan nonmesin, secara kimiawi menggunakan herbisida. Gulma pada pertanaman jagung umumnya dikendalikan dengan cara mekanis dan kimiawi. Pengendalian gulma secara kimiawi berpotensi merusak lingkungan sehingga perlu dibatasi melalui pemaduan dengan cara pengendalian lainnya (Fadly dan Tabri, 2007).

Sumatera Barat merupakan salah satu willayah yang kayak akan hasil pertaniannya. Banyak jenis tanaman yang dikelola oleh masyarakat disana, seperti tanaman jagung. Hasil survei lapangan yang telah dilakukan di Kelurahan Lambung Bukit, Padang, Sumatera Barat terdapat lahan pertanaman jagung dengan kondisi lingkungan sekitar pertanaman memperlihatkan banyaknya gulma yang tumbuh di sekitar area pertanaman tersebut. Hal ini akan memicu persaingan untuk tumbuh dan berkembang pada tanaman jagung dengan gulma yang berada di sekitar lahan pertanaman jagung tersebut. Rendahnya hasil jagung yang dicapai disebabkan banyaknya faktor, diantaranya pengeloalaan gulma belum dilaksanakan secara maksimal. Sehingga, pertumbuhan dan produksi jagung akan menurun.

Berdasarkan latar belakang diatas perlu dilakukan penelitian yang berjudul "Analisa Vegetasi Gulma Pada Pertanaman Jagung dan Hubungannya dengan Pengendalian Gulma di Kelurahan Lambung Bukit, Padang, Sumatera Barat". Diharapkan hasil penelitian ini nantinya dapat dijadikan sebagai panduan dalam tindakan pengendalian gulma pada pertanaman jagung di Kelurahan Lambung Bukit, Padang, Sumatera Barat.

\section{BAHAN DAN METODE}

\begin{abstract}
Alat dan Bahan
Alat yang diperlukan adalah tali rafia, koran, karung, selotip, oven, kamera digital, pancang, hp, alat-alat tulis, plastik $5 \mathrm{~kg}$, label gantung dan buku determinasi gulma (buku Weeds Of Rice In Indonesia (Soerjani et al., 1987), Atlas Of 220 Weeds Of Sugarcane Field In Java (Backer, 1973), The World's Worst Weeds (Le Roy G. Holm et al., 1988). Bahan yang diperlukan adalah jenis-jenis gulma pada pertanaman jagung dan alkohol $70 \%$.
\end{abstract}

\section{Metode Penelitian}

Penelitian dilakukan dengan Metode Kuadrat dengan menggunakan plot ukuran $1 \times 1 \mathrm{~m}^{2}$. Peletakan plot dilakukan secara sistematik yang diambil sebanyak 10 plot untuk tiap luasan pertanaman jagung. Untuk mengetahui tentang pengendalian gulma yang ada pada pertanaman jagung di Kelurahan Lambung Bukit, Padang, Sumatera Barat dibutuhkan wawancara secara langsung kepada pemilik lahan pertanaman jagung tersebut. Jenis gulma yang belum diketahui namanya dikoleksi dan selanjutnya 
diidentifikasi di Herbarium Universitas Andalas.

\section{HASIL DAN PEMBAHASAN}

\section{Komposisi Gulma}

Tabel 1 menunjukkan bahwa hasil analisis vegetasi gulma pada pertanaman jagung di Kelurahan Lambung Bukit, Padang, Sumatera Barat didapatkan 10 famili, 15 genus, 16 jenis, dan 1892 individu gulma. Pada pertanaman jagung di Kelurahan Lambung Bukit, Padang, Sumatera Barat, banyak ditemukan gulma dari famili Rubiaceae yaitu sebanyak 959 individu. Selain famili Rubiaceae, dua famili lain yang banyak ditemukan adalah Poaceae (143 individu) dan Compositae (735 individu). Sedangkan famili yang paling sedikit ditemukan adalah Cyperaceae (1 individu).

Banyak faktor yang mempengaruhi keragaman komunitas gulma pada pertanaman jagung ini di antaranya yaitu deposit biji gulma dalam tanah. Biji gulma dapat tersimpan dan bertahan hidup selama puluhan tahun dalam kondisi dorman, dan akan berkecambah ketika kondisi lingkungan mematahkan dormansi itu. Terangkatnya biji gulma ke lapisan atas permukaan tanah dan tersedianya kelembaban yang sesuai untuk perkecambahan mendorong gulma untuk tumbuh dan berkembang. Biji spesies gulma setahun (annual spesies) dapat bertahan dalam tanah selama bertahun-tahun sebagai cadangan benih hidup atau viable seeds (Melinda, Owen and Bucher, 1998).

Jumlah jenis gulma yang terus hidup sangatlah bervariasi pada setiap areal tanam. Variasi ini timbul bermula dari kemampuan gulma itu sendiri. Potensi kehadiran gulma dalam satu daerah sangat tinggi yang disebabkan banyak faktor dan salah satunya adalah sistem pengolahan tanah. Menurut Moenandir (1993) bahwa biji gulma berpotensi untuk tumbuh menjadi satu populasi gulma bila keadaan menguntungkan. Bijibiji gulma dapat tumbuh mencapai jutaan jumlahnya dalam tanah dan terdiri dari banyak jenis.

Tabel 1. Komposisi Gulma Pada Pertanaman Jagung di Kelurahan Lambung Bukit, Padang, Sumatera Barat.

\begin{tabular}{|c|c|c|c|c|}
\hline No & Famili & Genus & Spesies & Jumlah Individu \\
\hline \multirow[t]{2}{*}{1} & Amaranthaceae* & Amaranthus & Amaranthus sp. & 1 \\
\hline & & & Amaranthus hybridus L. & 4 \\
\hline 2 & Achantaceae* & Graptophyllum & Graptophyllum sp. & 3 \\
\hline \multirow[t]{5}{*}{3} & Poaceae** & Eleusine & Eleusine indica (L) & 17 \\
\hline & & & Gaertn. & \\
\hline & & Echinocloa & $\begin{array}{l}\text { Echinochloa crus-galli } \\
\text { (L.) P. Beauv. }\end{array}$ & 96 \\
\hline & & Eragrostis & Eragrostis sp. & 3 \\
\hline & & Digitaria & $\begin{array}{l}\text { Digitaria ciliaris (Retz.) } \\
\text { Koeler. }\end{array}$ & 27 \\
\hline 4 & Onagraceae* & Ludwigia & Ludwigia perennis L. & 14 \\
\hline 5 & Phyllanthaceae* & Phyllanthus & Phyllanthus niruri L. & 12 \\
\hline 6 & Euphorbiaceae* & Euphorbia & Euphorbia hirta L. & 2 \\
\hline 7 & Cyperaceae $* * *$ & Cyperus & Cyperus cephalotes Vahl. & 1 \\
\hline \multirow[t]{2}{*}{8} & Rubiaceae* & Hedyotis & Hedyotis sp. & 1 \\
\hline & & Borreria & Spermacoce alata Aubl. & 958 \\
\hline 9 & Cleomaceae* & Cleome & Cleome rutidosperma DC. & 18 \\
\hline \multirow[t]{2}{*}{10} & Compositae* & Ageratum & $\begin{array}{l}\text { Ageratum conyzoides (L.) } \\
\text { L. }\end{array}$ & 703 \\
\hline & & Galinsoga & Galinsoga parviflora Cav. & 32 \\
\hline
\end{tabular}

Keterangan: $* * *=$ teki-tekian, $* *=$ rerumputan $($ gulma berdaun sempit), $*=$ berdaun lebar 


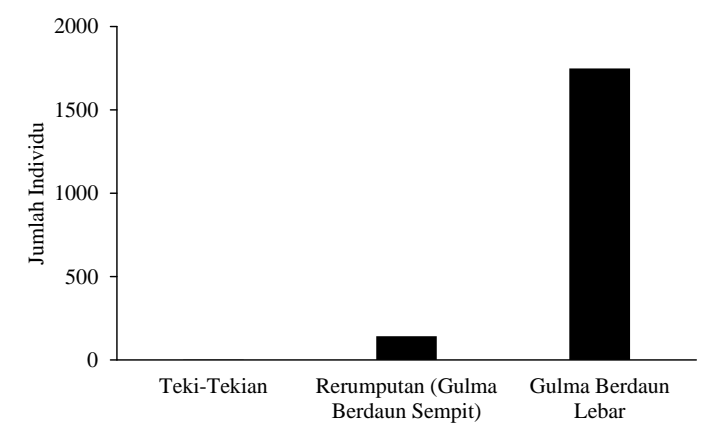

Gambar 1. Distribusi Gulma Berdasarkan Golongan di Pertanaman Jagung Kelurahan Lambung Bukit, Padang, Sumatera Barat.

Pada Gambar 1, dapat dilihat bahwa ditribusi gulma terbanyak pada pertanaman jagung pada Kelurahan Lambung Bukit, Padang, Sumatera Barat berasal dari golongan gulma berdaun lebar (1748 individu). Gulma golongan berdaun lebar sebagian besar temasuk tumbuhan berkeping dua (Dicotyledoneae) dari berbagai famili. Ciriciri umum adalah batang tubuh tegak dengan percabangannya, ada pula yang tumbuh merambat. Daun tunggal maupun majemuk, helaian daun bulat/bulat telur Bertulang daun melengkung atau menjari dan tepi daun rata, bergerigi atau bergelombang. Duduk daun berhadapan atau berselangseling. Bunga tunggal atau majemuk tersusun dalam suatu karangan bunga (Tjokrowardojo dan Djauhariya, 2011). Gulma berdaun lebar ini banyak ditemukan karena umumnya memiliki perakaran tunggang (Suryaningsih, Joni dan Darmadi, 2011). Sistem perakaran tunggang ini membuat gulma berdaun lebar jauh lebih kokoh dibandingkan dengan jenis rerumputan (gulma berdaun sempit) dan tekitekian. Sehingga, gulma berdaun lebar lebih mendominasi pada lahan pertanaman jagung tersebut.

\section{Family Dominan dan Co-Dominan}

Pada Tabel 2, dapat dilihat bahwa famili yang dominan pada lahan pertanaman jagung di Kelurahan Lambung Bukit, Padang, Sumatera Barat, yaitu famili Rubiaceae $(50,69 \%)$ dan family yang codominan pada famili Cyperaceae $(0.05 \%)$. Menurut Johnston and Gillman (1995), suatu famili dikatakan dominan pada suatu kawasan yaitu jika memiliki persentase $>20 \%$ dari total individu dan co-dominan jika persentasenya $10 \%-20 \%$.
Tabel 2. Famili Dominan dan Co-dominan Pada Pertanaman Jagung di Kelurahan Lambung Bukit, Padang, Sumatera Barat

\begin{tabular}{ccc}
\hline No & Famili & Persentase \\
\hline 1 & Rubiaceae & $50,69 \%$ \\
2 & Cyperaceae & $0,05 \%$ \\
\hline
\end{tabular}

\section{Struktur Gulma}

Pada Gambar 2, dapat diketahui bahwa gulma yang memiliki nilai SDR tertinggi yaitu gulma jenis Spermacoce alata Aubl. $(23,17 \%)$.

Gulma pertama yang mendominansi adalah Spermacoce alata famili (Rubiaceae) dengan nilai SDR 23,17 \%. Gulma ini tergolong berdaun lebar, mempunyai partumbuhan yang cepat dan besar-besar selain itu percabangan yang cukup banyak mengakibatkan untuk menghasilkan biji menjadi banyak sehingga biomasanya menjadi tinggi. Gulma ini tahan terhadap naungan, memiliki kerapatan yang tinggi dan penyebaran merata, menyebabkan gulma ini menjadi salah satu gulma yang dominan. Tingginya komunitas gulma Spermacoce alata ini karena kerapatan mutlaknya lebih tinggi dan penyebaran yang merata dengan kondisi vegetasi yang padat dan kanopi gulma yang menutupi permukaan tanah dapat merangsang partumbuhan gulma ini menjadi dominan. Berkembang biak dengan biji dan ruas batang yang keluar akar. Tumbuh di tempat terbuka atau agak terlindung hingga $1.700 \mathrm{~m} \mathrm{dpl}$ (Tjokrowardojo dan Djauhariya, 2011).

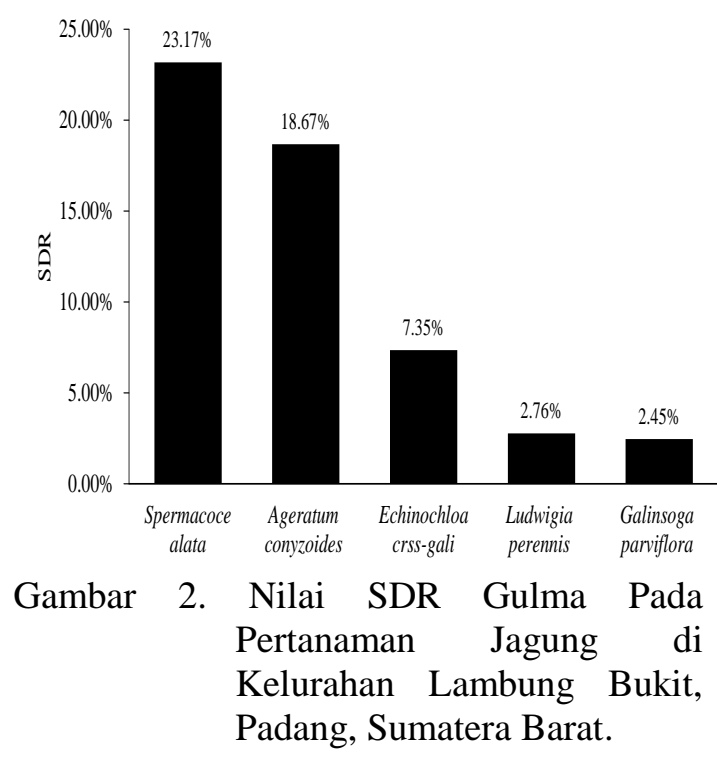


Gulma kedua yang mendominansi adalah Ageratum conyzoides famili (Asteraceae) dengan nilai SDR 18,67\%. Gulma Ageratum conyzoides termasuk golongan tumbuhan semusim yang banyak tumbuh di lahan pertanian, perkebunan karet, palawija, kopi, tembakau, cengkeh dan kelapa sawit. Dapat ditemukan hingga ketinggian $3.000 \mathrm{mdpl}$, meyukai intensitas cahaya tinggi dan ternaungi. Ageratum conyzoides memiliki tekstur biji ringan dengan jumlah biji yang banyak, dapat tersebar dengan bantuan angin dan cukup mengganggu perkebunan. Tumbuhan ini memiliki daya saing yang tinggi, sehingga dengan mudah tumbuh dimana-mana dan sering menjadi gulma yang merugikan para petani (Okunade, 2002). Jenis ini berkembang biak dengan biji dan tumbuh di tempat terbuka atau agak terlindung (Tjokrowardojo dan Djauhariya, 2011).

Gulma ketiga yang mendominansi adalah Echinochloa crus-gali famili (Graminae) dengan nilai SDR 7,35\%. Menurut Altop dan Mennan (2011), gulma Echinochloa crus-gali memiliki distribusi yang luas, mampu beradaptasi pada berbagai aspek ekologi, toleran terhadap kondisi iklim kering dan kondisi anaerob, perkecambahan dan pertumbuhan yang cepat, produksi biji yang banyak, sehingga spesies ini menjadi gulma dominan di lebih dari 60 negara.

\section{Indeks Keanekaragaman Jenis}

Berdasarkan Tabel 3, dapat dilihat bahwa nilai indeks dari keanekaragaman jenis gulma berada pada nilai $\mathrm{H}^{\prime}=1,2005$. Hal ini sesuai dengan Magurran (2004) menyatakan bahwa nilai indeks keanekaragaman Shannon yaitu $1>\mathrm{H} \geq 3$ menunjukkan keanekaragaman sedang. Odum (1996) juga menyatakan bahwa tinggi rendahnya keanekaragaman jenis suatu organisme didalam komunitasnya tergantung pada banyaknya jumlah individu yang terdapat pada komunitas tersebut. Kondisi lingkungan sangat mempengaruhi keanekaragaman jenis suatu tumbuhan. Kondisi yang sangat ekstrim akan menyebabkan gangguan terhadap stabilitas kehidupan dan distribusi beragam tumbuhan (Ewusie, 1990). Keanekaragaman jenis yang tinggi merupakan indikator dari kemantapan atau kestabilan dari suatu lingkungan partumbuhan. Kestabilan yang tinggi menunjukkan tingkat kompleksitas yang tinggi, hal ini disebabkan terjadinya interaksi yang tinggi pula sehingga akan mempunyai kemampuan lebih tinggi dalam menghadapi gangguan terhadap komponen-komponennya.

Tabel 3. Indeks Keanekaragaman Gulma Pada Pertanaman Jagung di Kelurahan Lambung Bukit, Padang, Sumatera Barat.

\begin{tabular}{|c|c|c|}
\hline No & Spesies & $\mathrm{H}^{\prime}$ \\
\hline 1 & Amaranthus sp. & $-0,0038$ \\
\hline 2 & Amaranthus hybridus L. & $-0,0129$ \\
\hline 3 & Graptophyllum sp. & $-0,0103$ \\
\hline 4 & Eleusine indica $(\mathrm{L})$ Gaertn. & $-0,0424$ \\
\hline 5 & Echinochloa crus-galli (L.) P. Beauv. & $-0,1512$ \\
\hline 6 & Eragrostis sp. & $-0,0103$ \\
\hline 7 & Digitaria ciliaris (Retz.) Koeler. & $-0,0607$ \\
\hline 8 & Ludwigia perennis L. & $-0,0363$ \\
\hline 9 & Phyllanthus niruri L. & $-0,0319$ \\
\hline 10 & Euphorbia hirta L. & $-0,0075$ \\
\hline 11 & Cyperus cephalotes Vahl. & $-0,0038$ \\
\hline 12 & Hedyotis sp. & $-0,0038$ \\
\hline 13 & Spermacoce alata Aubl. & $-0,3446$ \\
\hline 14 & Cleome rutidosperma DC. & $-0,0442$ \\
\hline 15 & Ageratum conyzoides $(\mathrm{L}.) \mathrm{L}$. & $-0,3679$ \\
\hline \multirow[t]{3}{*}{16} & Galinsoga parviflora Cav. & $-0,0689$ \\
\hline & $\Sigma$ Pi $\ln$ pi & $-1,2005$ \\
\hline & H' & 1,2005 \\
\hline
\end{tabular}




\section{Hubungannya Dengan Pengendalian Gulma}

Berdasarkan hasil wawancara yang telah dilakukan, pemilik melakukan pengendalian gulma secara mekanik, dilakukan sebelum lahan disiangi, tidak menggunakan herbisida. Setelah tanaman jagung tumbuh cukup besar umumnya gulma dibiarkan saja tumbuh. Cara pengendalian yang dilakukan ini sangat berhubungan pada pertumbuhan gulma karena pengendaliannya hanya dilakukan sebelum lahan disiangi dan metode pengendalian gulma yang dipakai hanya secara mekanik saja. Hal ini memicu gulma semakin banyak tumbuh pada lahan pertanaman jagung ini.

Pengendalian gulma dilakukan tidak hanya mutlak dengan satu metode saja tetapi dengan gabungan beberapa metode. Seperti, pemilik menggabungkan cara mekanis dan kimiawi dalam pemberantasan gulma ini. Pengertian 'pengendalian gulma dengan gabungan beberapa metode secara tepat' adalah menetapkan gabungan beberapa metode yang sesuai dengan keadaan tanaman dan lingkungan disesuaikan dengan ketersediaan peralatan, tenaga terampil, bahan-bahan, dan yang tak kalah pentingnya yakni dengan pengeluaran biaya semurah mungkin dan aman terhadap lingkungan terutama manusia. Menekan populasi gulma dan mempertahankan pada tingkat yang tidak merugikan berarti mengendalikan gulma agar tumbuh pada tingkat kerapatan dan tinggi tertentu agar hanya terdiri dari jenis-jenis yang tidak menimbulkan kerugian yang berarti.

Keberhasilan pengendalian gulma merupakan salah satu faktor penentu tercapainya tingkat hasil jagung yang tinggi. Gulma dapat dikendalikan melalui berbagai aturan dan karantina; secara biologi dengan menggunakan organisme hidup; secara fisik dengan membakar dan menggenangi, melalui budi daya dengan pergiliran tanaman, peningkatan daya saing dan penggunaan mulsa; secara mekanis dengan mencabut, membabat, menginjak, menyiang dengan tangan, dan mengolah tanah dengan alat mekanis bermesin dan nonmesin, secara kimiawi menggunakan herbisida. Gulma pada pertanaman jagung umumnya dikendalikan dengan cara mekanis dan kimiawi. Pengendalian gulma secara kimiawi berpo- tensi merusak lingkungan sehingga perlu dibatasi melalui pemaduan dengan cara pengendalian lainnya (Efendi dan Fadhly, 2004).

Pengelolaan gulma terpadu merupakan konsep yang mengutamakan pengendalian secara alami dengan menciptakan keadaan lingkungan yang tidak menguntungkan bagi perkembangan gulma dan meningkatkan daya saing tanaman terhadap gulma. Ada beberapa hal yang perlu mendapat perhatian dalam pengendalian secara terpadu: (1) pengendalian gulma secara langsung dilakukan dengan cara fisik, kimia, dan biologi, dan secara tidak langsung melalui peningkatan daya saing tanaman melalui perbaikan teknik budi daya, (2) memadukan cara-cara pengendalian tersebut, dan (3) analisis ekonomi praktek pengendalian gulma (Rizal, 2004).

Pengelolaan gulma secara terpadu pada prinsipnya memanipulasi faktor pertanaman sehingga lebih menguntungkan bagi tanaman. Tollenar et al. (1994), secara kuantitatif menyimpulkan pengaruh kepadatan tanaman jagung terhadap gulma selama daur pertumbuhan: (i) gangguan gulma selama pertumbuhan jagung menjadi kecil jika gulma disingkirkan hingga stadia 3-4 helai daun jagung, (ii) pada saat kepadatan tanaman jagung meningkat dari 4 menjadi 10 tanaman $/ \mathrm{m}^{2}$, biomas gulma menurun hingga $50 \%$.

Pengelolaan gulma secara terpadu mengkombinasikan efektivitas dan efisiensi ekonomi. Jika penggunaan herbisida dikurangi maka pengolahan tanah setelah tanam diperlukan (Buchler et al., 1995). Pengolahan tanah dapat mencegah perkembangan resistensi populasi gulma terhadap herbisida, mengurangi ketergantungan terhadap herbisida, dan menunda atau mencegah peningkatan spesies gulma tahunan yang sering menyertai dan timbul bersamaan dengan pengolahan konservasi (Staniforth and Wiese, 1985). Pada saat penggunaan herbisida diminimalkan atau dikurangi, pengolahan tanah setelah tanam diperlukan untuk mengendalikan gulma. Mengurangi pengolahan tanah lebih efisien dalam penggunaan energi daripada mengurangi penggunaan herbisida (Clements et al., 1995). 


\section{KESIMPULAN}

1. Komposisi gulma lahan pertanaman jagung di Kelurahan Lambung Bukit, Padang, Sumatera Barat didapatkan 10 famili, 15 genus, 16 jenis dan 1892 individu gulma.

2. Struktur gulma yang dominan pada pertanaman jagung ini adalah Spermacoce alata famili (Rubiaceae) dengan nilai SDR 23,17 \% dan nilai SDR terendah Hedyotis sp., Cyperus cephalotes dan Amaranthus sp. (0,65\%).

3. Nilai indeks dari keanekaragaman jenis gulma berada pada nilai $\mathrm{H}^{\prime}=1,2005$ (sedang).

4. Pengelolaan gulma terpadu merupakan konsep yang mengutamakan pengendalian secara alami dengan menciptakan keadaan lingkungan yang tidak menguntungkan bagi perkembangan gulma dan meningkatkan daya saing tanaman terhadap gulma.

\section{DAFTAR PUSTAKA}

Altop, E.K. and H. Mennan. 2011. Genetic and morphologic diversity of Echinochloa crus-galli populations from different origins. Phytoparasitica 39, 93-102.

Backer. 1973. Atlas Of 220 Weeds Of Sugarcane Field In Java. Jakarta.

Buchler, D.B., J.D. Doll, R.T. Proost, and M.R. Visocky. 1995. Integrating mechanical weeding with reduce herbicide use in conservation tillage corn production systems. Agron. J. 87:507-512.

Clements, D.R., S.F.Wiese, R. Brown, D.P. Stonehouse, D.J. Hume, and C.J. Swanton. 1995. Energy analysis of tillage and herbicide inputs in alternative weed management systems. Agriculture, Ecosystems and Environment. 52:119-128.

Efendi, R. dan A.F. Fadhly. 2004. Pengaruh sistem pengolahan tanah dan pemberian pupuk NPKZn terhadap pertumbuhan dan hasil jagung. Risalah Penelitian Jagung dan Serelaia Lain. 9:15-22.

Ewusie, J. Y. 1990. Pengantar Ekologi Tropika. ITB Press. Bandung.

Fadhly, A. F, dan F. Tabri. 2007. Pengandalian Gulma pada Pertanaman

Jagung.http://balit.litbang.co.id.bukuja gung.pdf. 02 April 2016.

Johnston and Gillman. 1995. Tree Population Study in ow Diversity Forest Guyana.i. Floristc Composition and Stand Structure. Biodiversity and Conversation. 4;339-362.

Kastanja, A.Y. 2012. Identifikasi Jenis dan Dominansi Gulma Pada Pertanaman Padi Gogo. (Studi Kasus di Kecamatan Tobelo Barat, Kabupaten Halmahera Utara). Balai Penyuluhan Pertanian. Halmahera Utara.

Le Roy G. Holm, Ronald L.Plucknett, Juan V. Pancho, James P. Herberger .1988. The World's Worst Weeds. University Press Of Hawai.

Melinda, L.H., M.D.K. Owen, and D.D. Bucher. 1998. Effects Of Crop And Weed Management On Density And Vertical Distribution Of Weed Seeds In Soil. Agron. J. 90:793-799.

Moenandir, J . 1990. Persaingan Tanaman Budidaya Dengan Gulma. Penerbit CV. Rajawali.Jakarta.

Moenandir, J. 1993. Ilmu Gulma Dalam Sitem Pertanian. PT. Gadjah Mada University Press. Yogyakarta.

Purwono dan Hartono, R. 2008. Bertanam Jagung Unggul. Penebar Swadaya. Jakarta.

Rizal, A. 2004. Penentuan kehilangan hasil tanaman akibat gulma. Dalam: S. Tjitrosemito, A.S. Tjitrosoedirdjo, dan 
I. Mawardi (Eds.) Prosiding Konferensi Nasional XVI Himpunan Ilmu Gulma Indonesia, Bogor, 15-17 Juli 2003. 2: 105-118.

Rukmana, H.R. dan U.S. Saputra. 1999. Gulma dan Tehnik Pengendalian. Kanisius. Jakarta.

Soerjani, M. Koestermans, A.J.G.H and G. Tjitrosoepomo, 1987. Weed of Rice in Indonesia. Balai Pustaka. Jakarta.

Staniforth, D.W. and A.F. Wiese. 1985. Weed biology and its relationship to weed control in limited tillage systems. In: A.F. Wiese (Ed.). Weed Control in Limited Tillage Systems. Weed Sci. Soc. Am. Champaign. IL. p.15-25.

Suarni., 2001. Tepung Komposit Sorgum, Jagung, dan Beras untuk Pembuatan Kue Basah (cake). Risalah Penelitian Jagung dan Serealia Lain. Balai Penelitian Tanaman Jagung dan Serealia. Maros.

Suryaningsih, M. Joni dan A. A. K. Darmadi. 2011. Inventarisasi Gulma Pada Tanaman Jagung (Zea Mays L.) Di Lahan Sawah Kelurahan Padang Galak, Denpasar Timur, Kodya Denpasar, Provinsi Bali. Jurnal Simbiosis. Universitas Udayana. Bali.

Tjokrowardojo, A.S. dan E. Djauhariya. 2011. Gulma dan Pengendaliannya Pada Budidaya Tanaman Nilam. Nilam (Pogostemon cablin Benth): Status Teknologi Hasil Penelitian Nilam. p.40-49.

Tollenaar, M., A.A. Dibo, A. Aquilera, S.F. Weise, and C.J. Swanton. 1994. Effect of weed interference and soil nitrogen on four maize hybrids. Agron. $J$. 86:596-601.

Odum, E. P. 1996. Dasar-Dasar Ekologi. Gadjah Mada University Press. Yogyakarta.
Okunade, A.L. 2002. Ageratum conyzoides L. Asteraceae. Fitoterapia. 73: 1-16.

Violic, A.D. 2000. Integrated crop menagement. In: R.L. Paliwal, G. Granados, H.R. Lafitte, A.D. Violic, and J.P. Marathee (Eds.). Tropical Maize Improvement and Production. FOA Plant Production and Protection Series, Food and Agriculture Organization of The United Nations. Rome, 28:237-282. 